原 著論 文

義歯装着者の口腔乾燥感に関する臨床的研究

第 1 報 アンケート調査結果

高山 慈子 西村 克彦 東條 敏明 細井 紀雄

\title{
A Clinical Study on the Feeling of Oral Dryness in Denture Wearers
}

Part 1. Results of a Questionnaire Survey

Takayama Yasuko, Nishimura Katsuhiko, Tojo Toshiaki and Hosoi Toshio

\section{歯科補経学的意義}

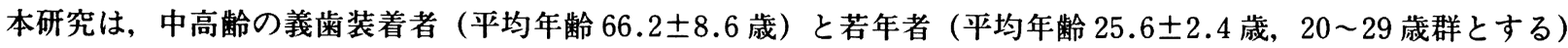
の口腔乾燥感に関する自覚症状の比較, さらに乾燥感と義歯との関連性を把握する目的で調查を行ったものである. アンケート調查から, 乾燥感自覚者は義㐘装着者群では $48 \%$ を占め, $20 \sim 29$ 歳群の $22 \%$ に対し有意に高かった。 義歯装着者群では，義歯の形態などにより乾燥感の自覚症状に差はみられなかった。

抄 録

目的：本研究は, 中高齢の義歯装着者と若年者の口腔乾燥感に関する自覚症状の比較, ならびに義歯装 着者における口腔乾燥感と義歯との関連性を把握する目的で調査を行ったものである.

方法：2003 年 6 10 月に鶴見大学歯学部附属病院補綴科に来院した中高齢の義歯装着患者 100 名（平 均年齢 $66.2 \pm 8.6$ 歳）および若年者 50 名（平均年齢 $25.6 \pm 2.4$ 歳，以後 $20 \sim 29$ 歳群とする）に調査を 行った．調査はアンケートおよびロ腔内や義歯に関する診査である．アンケート調查は，口腔乾燥感に 関する自覚症状や全身状態, 服用中の薬剤などに関するものである. 口腔内や義歯に関する調査は, 残 存歯の状態, 補綴装置, 義歯の形態や材料などである.

結果：義歯装着者では口腔乾燥感自覚者は 48\% を示し，20２9 歳群の $22 \%$ に比べて有意に高かった $(\mathrm{p}<0.01)$. 乾燥感の自覚症状と性別, 服用薬凨, 残存歯数, 修復歯数などとの関連は認められなかっ た.また義歯装着者群においても, 補経装置の種類（義歯を装着していない・部分床義歯・全部床義 歯）や義歯の形態，材料で乾燥感の自覚症状に有意差は認められなかった。

結論：義歯装着者の口腔乾燥感自覚者は，20～29 歳群に比べて有意に高かった．義歯装着者群では， 義歯の種類や形態，材料などによって乾燥感の自覚症状に差がみられなかった， 口腔乾燥感の発現に関 連する因子については今後さらに検討が必要である.

和文キーワード

口腔乾燥感, アンケート，義歯装着者，義歯床，服用薬䩹

鶴見大学歯学部歯科補綴学第一講座

The First Department of Prosthetic Dentistry, Tsurumi University School of Dental Medicine (Chief : Prof. Hosoi Toshio) 受付 : 2004 年 9 月 15 日/受理：2005 年 1 月 28 日

Received on September 15, 2004/Accepted on January 28, 2005 


\section{I. 緒 言}

近年日常臨床で，口腔乾燥感を訴える患者が少なく ない，齊藤 ${ }^{11}$ は, 口腔乾燥症（ドライマウス）は口渴 を自覚するだけの症状から，明らかな唾液の量的また は質的異常により引き起こされた口腔の機能障害を示 す病態と定義している。しかし，わが国では口腔乾燥 症に関する明確な定義は確立されておらず，疫学的調 査も十分とはいえない，腔乾燥症はさまざまな原因 により生じることが知られており，現在主な原因とし て挙げられているのは, 薬剤, 精神的なストレス, 放 射線治療, シェーグレン症候群, 糖尿病などである。 一般の人を対象にした調査では，およそ 4 人に 1 人が 口腔乾燥症あるいはそれに関する症状がみられ，また 高齢者では約 $40 \%$ が口腔乾燥症を訴えたと報告され ている2).また， 65 歳以上の高齢者の約 $55 \%$ が口腔 乾燥感を自覚しているとの報告もある33. 高齢者では 適切な唾液分泌を阻害する条件が多くなることから， 唾液分泌減少の診断と対処がしばしば臨床上の重要な 課題となる. しかし, 加齢と唾液分泌能に関してはこ れまで意見の一致がみられず，加齢に伴い唾液量が減 少するという報告 ${ }^{4 \sim 6)}$ のる一方，健常人であれば基 本的に加齢による唾液分泌の減少はみられないとする 報告も多( ${ }^{7 \sim 13)}$ ．唾液の分泌が低下すると，義歯装着 患者では，義歯の維持不良や粘膜の炎症，裖瘔性潰瘍 などが生じやすい.これまで各地域で各人種をふまえ た多くの研究が行われてきたが，通常の日常生活を送 る義歯装着患者を対象とした詳細な調査は，ほとんど 行われていない3,14,15).

本研究は，中高齢の義歯装着者と若年者の口腔乾燥 感に関する自覚症状の比較，ならびに義歯装着者にお ける口腔乾燥感と義歯との関連性を把握する目的で調 査を行ったものである.

\section{II. 方 法}

調査は, 2003 年 6〜10月に鶴見大学歯学部附属病 院補綴科へ来院した義歯装着患者のうち，本研究に同 意の得られた中高齢の義歯装着者 100 名および若年者 群として本学学生および臨床研修歯科医 50 名を対象 とした（鶴見大学歯学部倫理審査委員会承認, 平成
15 年 5 月 20 日, 受付番号 106). 義歯装着者群は 46〜 85 歳までの男性 33 名 (平均年齢 $66.1 \pm 8.5$ 歳), 女 性 67 名（平均年齢 $66.3 \pm 8.5$ 歳）で, 平均年齢 は $66.2 \pm 8.6$ 歳である (以後義歯装着者群とする)。ま た, 若年者群は 20〜29 歳までの男性 31 名（平均年齢 $25.1 \pm 2.3$ 歳), 女性 19 名（平均年齢 $25.3 \pm 2.6$ 歳） で，平均年齢は $25.6 \pm 2.4$ 歳である（以後 $20 \sim 29$ 歳 群とする).

調査項目は口腔乾燥に関する自覚症状や服用中の薬 剤などに関するアンケート調査，口腔内および義歯に 関する診査である（表 $1 ， 2$ ）。アンケート調査は，柿 木らが用いた「口腔の乾燥度に関する調査票」に準じ $た^{33}$. また義歯の形態を 4 型に分類し, 乾燥感との関 連性について検討した（図 1)。

統計分析は $\chi^{2}$ 検定を用いた。

\section{III. 結 果}

\section{1. 口腔乾燥感に関する自覚症状}

1）口腔乾燥に関するアンケート

表 3 に口腔乾燥感および口腔乾燥に関連する質問事 項（アンケート用紙・質問事項 2) の調査結果を示 す．各質問に「時々・少し」あるいは「ある」と答え た者を自覚者とすると，自覚者が多かった項目は 20 〜29歳群では「汗をかきやすい」,「口で息をする」, 「水をよく飲む」, 義歯装着者群では「汗をかきやす い」,「口の中が乾く」,「水をよく飲む」であった，自 覚者の少ない項目は 20〜29 歳群, 義歯装着者群とも に「食物を飲みにくい」，「味がおかしい」であった。 「目が乾きやすい」は 20〜29 歳群に,「口の中が乾 く」,「乾いた食品が食べにくい」,「口の中がネバネバ する, 話しにくい」は義歯装着者群に多く, 2 群間に 有意差が認められた $(\mathrm{p}<0.01)$.「口の中が乾く, カ ラカラする」という口腔乾燥感に関する直接的な質問 は, 20～29歳群で「ある」が 1 名 (2\%), 「時々・少 し」が 10 名 (20\%)，「なし」が 39 名 (78\%) であ り, 義歯装着者群では「ある」が 12 名 (12\%), 「時々・少し」が 36 名 (36\%)，「なし」が 52 名 （52\%）であった．以後，この質問に対して自覚を有 するものを「乾燥感自覚者」とする.

乾燥感の自覚症状の有無で, 質問 2〜13 に対する回 答（各質問に対する自覚症状の有無）に有意差が認め 
表 1 Questionnaire about the feeling of oral dryness 口腔乾燥感に関するアンケート

How old are you? Sex (Male/Female) How tall are you? What is your weight?

$\underline{\text { Please circle each applicable item }}$

1. General condition

0 . No special disorder

1. Hypertension

2. Diabetes mellitus

3. Gastrointestinal disorder 4. Respiratory disorder

6. Cardiac failure

7. Hepatic disorder

5. Cardiac disorder

9. Parkinson's disorder

10. Renal disorder

8. Blood disorder

12. Psychosmatic disorder

13. Psychiatric disorder

11. Urinary tract disorder

14. Others (A. Bronchial asthma B. Allergic rhinitis

2. Symptoms

1) The mouth becomes dry and parched

2) I often drink water and always bring water with me

3) I wake up in the middle of night and drink water

4) Eating dry foods such as crackers is difficult

C. Pollinosis D. Atopic dermatitis)

5) Swallowing food is difficult

6) My mouth is sticky, and talking is difficult

7) Foods taste strange

8) I breathe through my mouth (including breathing during sleep)

$\underline{0(\mathrm{No}) \cdot 1 \text { (Sometimes/a little) } \cdot 2(\mathrm{Yes})}$

$\frac{0 \cdot 1 \cdot 2}{0 \cdot 1 \cdot 2}$

9) I am told that I have foul breath/I am nervous about foul breath

$\underline{0 \cdot 1 \cdot 2}$

10) My eyes tend to become dry

$0 \cdot 1 \cdot 2$

$\frac{0 \cdot 1 \cdot 2}{0 \cdot 1 \cdot 2}$

11) I tend to sweat

$\underline{0 \cdot 1 \cdot 2}$

12) My denture causes damage

13) My upper denture tends to be dislocated

3. About current medications and alchol ingestion (Circle 5 major items)
0 . No
1. Antihypertensive drug
2. Antihistaminic
4. Antidepressant
5. Antiparkinsonism drug 6. Diuretic
3. Tranquilizer
8. Antiallergic drug 9. Inhalant
10. Others
7. $\beta$-blocker

4. Smoking habits

No: Yes

5. About ( ) hours after a meal/About ( ) hours after tooth brushing

(和訳)

年齢 歳, 性別 (男・女), 身長 $\mathrm{cm}$, 体重 $\mathrm{Kg}$

以下は，該当するものに○印をつけてください

1. 全身状態

0. 特になし 1. 高血圧 2. 糖尿病 3 . 消化器疾患 4 . 呼吸器疾患 5 . 心疾患 6 . 心不全

7. 肝臓疾患 8 . 血液疾患 9 . パーキンソン病 10 。 腎疾患 11 . 尿路疾患 12 . 心身症

13. 精神疾患 14 . その他 (A. 気管支喘息 B. アレルギー性鼻炎 C. 花粉症 D. アトピー性皮膚炎)

2. 自覚症状の該当するものに，○印を付けてください.

1) 口の中が乾く，カラカラする.

0 ない

2) 水をよく飲む，いつも持参している

0 . ない

1. 時々・少し

2.ある

3）夜中に起きて水を飲む

4）クラッカーなど乾いた食品が食べにくい

0 . ない

1. 時々・少し

2.ある

5) 食物が飲み込みにくい

0 .ない

1. 時々・少し

2. ある

0 .ない

1. 時々・少し

2.ある

6） 口の中がネバネバする，話しにくい

0 .ない

1. 時々・少し

2.ある

7）味がおかしい

0 .ない

1. 時々・少し

2.ある

8） 口で息をする（寝るときも含む）

9）口臭があると言われる，気になる

0 . ない

1. 時々・少し

2.ある

0 . ない

1. 時々・少し

2.ある

10）目が乾きやすい

0 . ない

1. 時々・少し

2.ある

11）汗をかきやすい

0 . ない

1. 時々・少し

2. ある

12）義歯で傷がつきやすい

0 . ない

1. 時々・少し

2.ある

13）上の義歯がはずれやすい

0 .ない

1. 時々・少し

2.ある

3. 薬の服用あるいはアルコールの飲用について

2.ある

0. 特になし 1. 抗高血圧剂 2 . 抗ヒスタミン剂 3 . 精神安定剂 4 . 抗うつ剂 5 . 抗パーキンソン剤

6. 利尿剤 7. $\beta$ 遮断剂 8. 抗アレルギー撤 9 . 吸入薬 10 . その他 11 . アルコール

4. 喫煙の習慣

ない：ある

5. 経過時間：食事をしてから約＼cjkstart時間・歯磨きをしてから約＼cjkstart時間 
表 2 Oral and denture examination 口腔内および義歯に関する診査

1. Condition of the remaining teeth (defective, restored)

2. The kinds of prosthesis (upper and lower jaws)

0 . No denture 1. Partial denture

2. Complete denture

3. Materials of dentures

4. Form of the denture base

Upper jaw

I : No

II : Bounded saddle denture or unilateral distal extension denture

III : The palatal mucosa is exposed partially

IV : The denture base covers the entire palatal mucosa

Lower jaw

I : No

II : Bounded saddle denture or unilateral distal extension denture

III : Lingual bar

IV : The denture base covers the entire lingual mucosa

Upper and lower jaws

I : Bounded saddle denture or unilateral distal extension denture in the either or both jaws

II : A denture under the above II $\sim$ IV type in only either jaw

III : The palatal mucosa and lingual mucosa is exposed partially, or the palatal mucosa or lingual mucosa is exposed partially

IV : The denture base covers the entire palatal mucosa and lingual mucosa

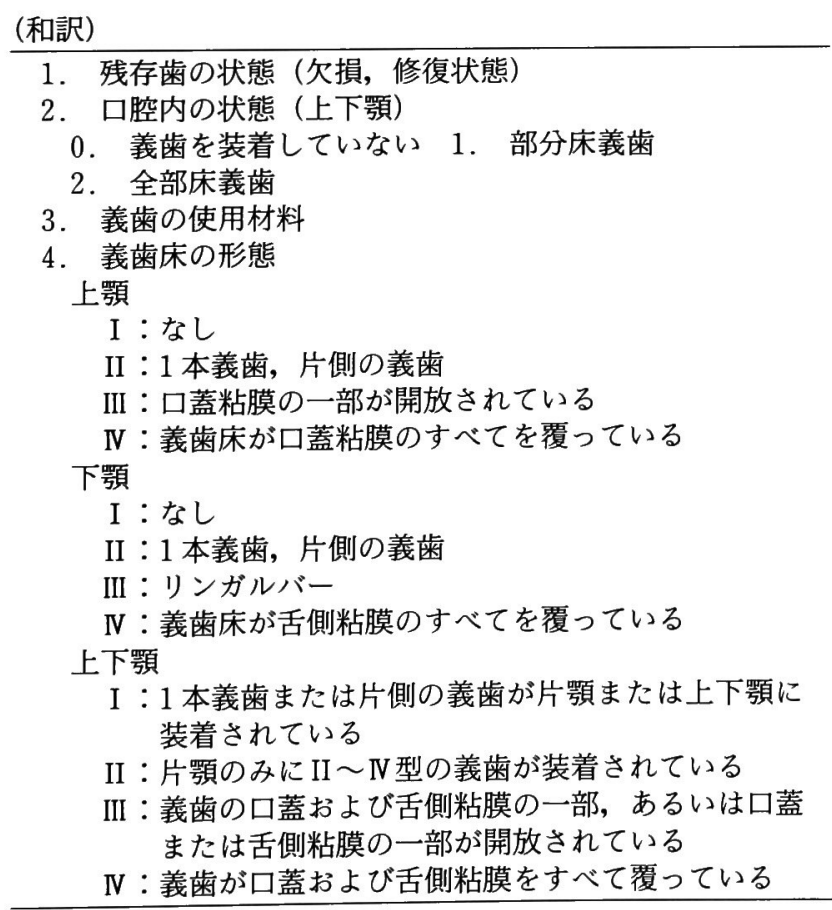

られた項目は，20〜29 歳群では「口臭が気になる」 の 1 項目で, 乾燥感の自覚症状のある者に口臭が気に なる者が多かった $(\mathrm{p}<0.01)$ 。これに対し義歯装着 者群では, 乾燥感の自覚症状の有無で「夜中に起きて 水を飲む」，「口で息をする」，「義歯で傷がつきやす い」 $(\mathrm{p}<0.01),\lceil$ 水をよく飲む, いつも持参してい る」,「食物が飲み込みにくい」（p<0.05）など 7 項 目に対する自覚症状の有無に有意差が認められた．特 に乾燥感自覚者では「口の中がネバネバする, 話しに くい」を自覚するものが $83.3 \%$, 「乾いた食品が食べ にくい」は $80.0 \%$ を占めた（p<0.01）.

2）年齢，性別，ボディマス指数

表 4 に年代別の口腔乾燥感の自覚症状の有無を示 す. 乾燥感自覚者は $20 \sim 29$ 歳群で $22 \%$, 義歯装着者 群で 48\%を示し， 2 群間に有意差が認められた（p< 0.01).また義歯装着者群を 40〜49，50～59，60～ 69, 70〜79 歳, 80 歳以上の 5 群に分けると, 各年代 による有意差は認められなかった。

乾燥感自覚者は, 20〜29 歳群では男性 19.4\%, 女 性 $26.3 \%$ ，義歯装着者群では男性 $45.5 \%$ ，女性

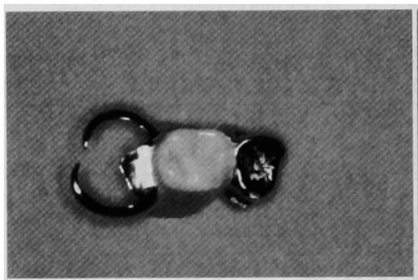

Type I

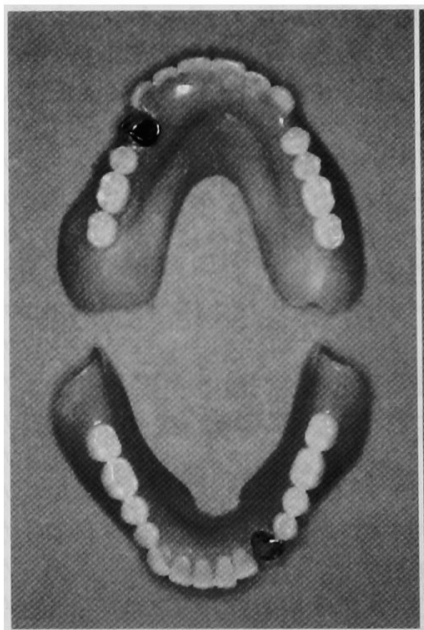

Type III

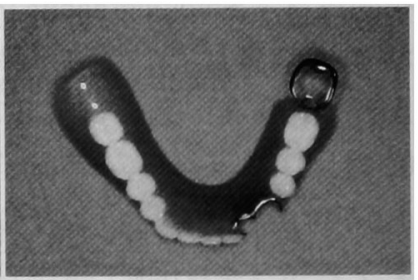

Type II

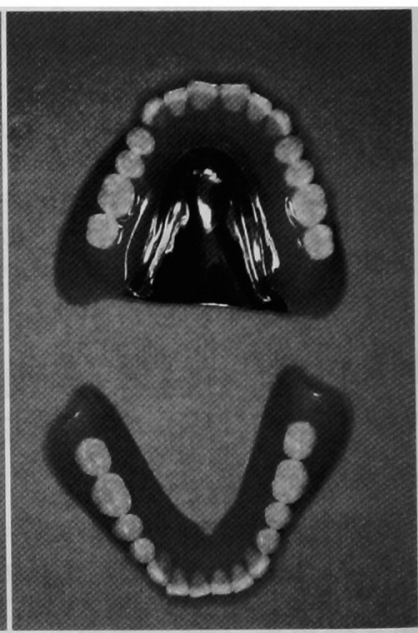

Type IV
図 1 The classification by the form of the denture base (Upper and lower jaws, type of $\mathrm{I} \sim \mathrm{IV}$ ) 義歯の形態による分類（上下顎，I ～IV 型） 
表 3 Result of symptoms about the feeling of oral dryness 口腔乾燥の自覚症状に関する結果

\begin{tabular}{|c|c|c|c|c|c|}
\hline \multirow{2}{*}{ Symptoms about the feeling of oral dryness } & \multicolumn{2}{|c|}{ 20-29 year-old } & \multicolumn{2}{|c|}{ Denture wearers } & \multirow{2}{*}{$\begin{array}{c}\text { chi-square } \\
\text { test }\end{array}$} \\
\hline & No & Yes & No & Yes & \\
\hline 1) The mouth becomes dry and parched & 39 & 11 & 52 & 48 & $* *$ \\
\hline 2) I often drink water and always bring water with me & 24 & 26 & 60 & 40 & NS \\
\hline 3) I wake up in the middle of night and drink water & 42 & 8 & 69 & 31 & $*$ \\
\hline 4) Eating dry foods such as crackers is difficult & 48 & 2 & 75 & 25 & $* *$ \\
\hline 5) Swallowing food is difficult & 50 & 0 & 89 & 11 & $*$ \\
\hline 6) My mouth is sticky, and talking is difficult & 46 & 4 & 70 & 30 & ** \\
\hline 7) Foods taste strange & 49 & 1 & 85 & 15 & $*$ \\
\hline 8) I breathe through my mouth (including breathing during sleep) & 21 & 29 & 69 & 31 & * \\
\hline 9) I am told that I have foul breath/I am nervous about foul breath & 39 & 11 & 63 & 37 & NS \\
\hline 10) My eyes tend to become dry & 29 & 21 & 81 & 19 & $* *$ \\
\hline 11) I tend to sweat & 18 & 32 & 42 & 58 & NS \\
\hline 12) My denture causes damage & 0 & 0 & 71 & 29 & NS \\
\hline 13) My upper denture tends to be dislocated & 0 & 0 & 81 & 19 & NS \\
\hline
\end{tabular}

No: The subjects answered "No" to each item. Yes: The subjects answered "Sometimes or a little" and "Yes" to each item. **: Statistically significant difference $(p<0.01), *$ : Statistically significant difference $(p<0.05)$, NS : No statistically significant difference

49.3\%で，いずれも女性のほうが多い傾向にあった が，性別による有意差は認められなかった。

平均ボディマス指数〔以後 BMI とする．体重 $(\mathrm{kg}) /$ 身長 $(\mathrm{m})^{2}$ 了 は, 20〜29 歳群では乾燥感なし群 が 20.90（標準偏差 SD 2.97），自覚者が 20.52（SD 1.58)，義歯装着者群では乾燥感なし群が 21.96（SD 2.97），自覚者が 22.13（SD 3.40）で両群間に有意差 は認められなかった。

\section{3）全身状態と服用中の薬剤}

20〜29 歳群では，「その他の疾患」に罹患している 15 名のうち乾燥感自覚者は $40.0 \%$ で, 疾患なし群 （35名）の $14.3 \%$ に比較して有意に高かった（ $\mathrm{p}<$ 0.05). 義歯装着者群では, 疾患なし群（43 名）の乾 燥感自覚者は $41.9 \%$ であったのに対し, 高血圧群 (26名) では $61.5 \%$, 糖尿病 (9 名) では $77.8 \%$, 消 化器疾患（6名）では 83.3\%，「その他の疾患」(23 名）では $39.1 \%$ を示したが，疾患なし群との間に有 意差は認められなかった。

表 5 に服用薬剤およびアルコール摂取と口腔乾燥感 との関係を示す．義歯装着者群では，精神安定剤や $\beta$ 遮断剤を服用しているものに乾燥感自覚者は多い傾向 にあったが，服薬なし群との間に有意差は認められな かった。また乾燥感自覚者は「服薬なし」で $41.7 \%$,「 1 種類の服薬」で $50.0 \%$,「2 種類以上の服 薬」では $64.3 \%$ を示し, 服薬の種類が多いほうが自 覚者は多い傾向にあった。アルコールの摂取と口腔乾
表 4 Result of symptoms about the feeling of oral dryness according to age groups 年代別の口腔乾燥感の自覚症状

\begin{tabular}{crrrr}
\hline \hline & & \multicolumn{3}{c}{ Symptom of oral dryness } \\
\cline { 3 - 5 } Age group & $\mathrm{N}$ & \multicolumn{1}{c}{ No } & Sometimes & Yes \\
\hline $20 \sim 29$ & 50 & $39(78.0)$ & $10(20.0)$ & $1(2.0)$ \\
\hline $40 \sim 49$ & 2 & $2(100.0)$ & $0(0.0)$ & $0(0.0)$ \\
$50 \sim 59$ & 21 & $10(47.6)$ & $9(42.9)$ & $2(9.5)$ \\
$60 \sim 69$ & 35 & $18(51.4)$ & $14(40.0)$ & $3(8.6)$ \\
$70 \sim 79$ & 39 & $19(48.7)$ & $13(33.3)$ & $7(18.0)$ \\
$80 \sim$ & 3 & $3(100.0)$ & $0(0.0)$ & $0(0.0)$ \\
\hline
\end{tabular}
Subjects $(\%)$

燥感の有無との間には関連は認められなかった。

\section{4）喫煙の有無}

20〜29 歳群では喫煙の習慣のない者は 31 名，ある 者が 19 名であった。乾燥感自覚者は喫煙の習慣のな い者が 6 名 (19.4\%)，ある者が 5 名 (26.3\%) で, 喫煙の有無で有意差は認められなかった．義歯装着者 群では, 喫煙の習慣のない者が 84 名, ある者が 16 名 であった，乾燥感自覚者は習慣のない者が 40 名 $(46.8 \%)$ ， ある者が 8 名 $(50.0 \%)$ で，喫煙の有無で は有意差は認められなかった。

\section{2. 口腔内の状態}

20〜29 歳群の平均残存歯数は上顎 $14.3 \pm 1.3$ 歯, 下顎 $14.3 \pm 1.2$ 歯, 平均修復歯数は上顎 $4.9 \pm 3.5$ 歯, 下顎 $3.7 \pm 1.9$ 歯であった。

義歯装着者群の平均残存歯数は上顎 $6.1 \pm 4.4$ 歯, 
下顎 $7.6 \pm 4.0$, 平均修復歯数は上顎 $3.9 \pm 3.4$ 歯, 下 顎 $3.5 \pm 2.8$ 歯, 義歯の平均補綴歯数は上顎 $8.0 \pm 4.9$ 歯, 下顎 $6.3 \pm 4.7$ 歯であった。

表 6 に口腔内の状態と乾燥感の自覚症状を示す. 20 ２9歳群, 義歯装着者群ともに, 乾燥感の自覚症状 で残存歯数, 欠損歯数, 修復歯数に有意差は認められ なかった。

\section{3. 義歯}

表 7 に義歯装着者群の補経装置の装着状態と乾燥感 の自覚を示す．補綴装置（義歯の装着なし・部分床・

表 5 Relationship between symptoms about the feeling of oral dryness and current medications and alcohol ingestion

服用楽剤およびアルコール攝取と口腔乾燥感の自覚症状

\begin{tabular}{lrrrrr}
\hline \hline \multirow{2}{*}{$\begin{array}{l}\text { Drugs and alcohol } \\
\text { ingestion }\end{array}$} & \multicolumn{2}{c}{$20-29$ year-old } & & \multicolumn{2}{c}{ Denture wearers } \\
\cline { 2 - 3 } \cline { 5 - 6 } \cline { 5 - 6 } 0. No & 44 & 10 & & Yes & Yes \\
No+Alcohol only & 45 & 11 & & 63 & 27 \\
1. Antihypertensive & 0 & 0 & 24 & 14 \\
$\quad$ drug & & & & \\
2. Antihistaminic & 2 & 0 & 0 & 0 \\
3. Tranquilizer & 0 & 0 & 10 & 7 \\
4. Antidepressant & 0 & 0 & 0 & 0 \\
5. Antiparkinsonism & 0 & 0 & 1 & 1 \\
drug & & & & \\
6. Diuretic & 0 & 0 & 2 & 1 \\
7. $\beta$-blocker & 0 & 0 & 9 & 7 \\
8. Antiallergic drug & 3 & 0 & 1 & 1 \\
9. Inhalant & 0 & 0 & 1 & 0 \\
10. Others & 0 & 0 & 0 & 0 \\
11. Alcohol & 3 & 1 & 20 & 8 \\
\hline
\end{tabular}

Yes: The subjects answered "Sometimes or a little" and "Yes" to item that the mouth becomes dry and parched
全部床義歯）では，乾燥感の自覚症状に有意差は認め られなかった。

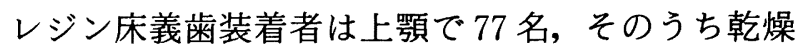
感自覚者は $49.4 \%$, 金属床義歯装着者は 11 名で自覚 者は $36.4 \% ，$ 下顎ではレジン床義歯装着者は 75 名で 自覚者は $49.3 \%$, 金属床義歯装着者は 8 名で自覚者 は $37.5 \%$ であった，金属床義歯装着者のほうが乾燥 感自覚者は少なかったが, 有意差は認められなかった。

表 7 Relationship between symptoms about the feeling of oral dryness and the kinds of prosthesis 補緅装置の種類と口腔乾燥感の自覚症状

\begin{tabular}{lrrr}
\hline \hline Upper jaw & & & \\
\hline & & \multicolumn{2}{l}{ Symptom of oral dryness } \\
\cline { 3 - 4 } \multicolumn{1}{c}{ Prosthesis } & $\mathrm{N}$ & No & \multicolumn{1}{c}{ Yes } \\
\hline No & 12 & $6(50.0)$ & $6(50.0)$ \\
Partial denture & 70 & $36(51.4)$ & $34(48.6)$ \\
Complete denture & 18 & $10(55.6)$ & $8(44.4)$ \\
\hline
\end{tabular}
Subjects $(\%)$

Lower jaw

\begin{tabular}{lrrr}
\hline & & \multicolumn{2}{c}{ Symptom of oral dryness } \\
\cline { 3 - 4 } \multicolumn{1}{c}{ Prosthesis } & $\mathrm{N}$ & No & \multicolumn{1}{c}{ Yes } \\
\hline No & 17 & $9(52.9)$ & $8(47.1)$ \\
Partial denture & 70 & $35(50.0)$ & $35(50.0)$ \\
Complete denture & 13 & $8(61.5)$ & $5(38.5)$ \\
\hline \multicolumn{3}{c}{ Subjects (\%) } \\
Upper and lower jaws & & \\
\hline \multirow{2}{*}{ Upper / Lower } & \multirow{2}{*}{ No } & Partial & Complete \\
& & denture & denture \\
\hline No & $0(0)$ & $11(5)$ & $1(1)$ \\
Partial denture & $15(7)$ & $47(25)$ & $8(2)$ \\
Complete denture & $2(0)$ & $12(6)$ & $4(2)$ \\
\hline
\end{tabular}

( ) : The subjects answered "Sometimes or a little" and "Yes" to item that the mouth becomes dry and parched

表 6 Relationship between symptoms about the feeling of oral dryness and oral condition 口腔内の状態と口腔乾燥感の自覚症状

\begin{tabular}{|c|c|c|c|c|c|}
\hline \multirow[b]{2}{*}{ Oral condition } & \multirow[b]{2}{*}{ Jaw } & \multicolumn{2}{|c|}{ 20-29 year-old } & \multicolumn{2}{|c|}{ Denture wearers } \\
\hline & & No & Yes & No & Yes \\
\hline \multirow[t]{2}{*}{ Remaining teeth } & Upper & $14.3(1.3)$ & $14.5(1.2)$ & $5.9(4.3)$ & $6.4(4.5)$ \\
\hline & Lower & $14.3(1.3)$ & $14.4(0.8)$ & $7.6(4.3)$ & $7.5(3.7)$ \\
\hline \multirow[t]{2}{*}{ Missing teeth } & Upper & $0.4(0.9)$ & $0.3(0.6)$ & $8.2(4.2)$ & $7.6(4.5)$ \\
\hline & Lower & $0.4(0.9)$ & $0.2(0.4)$ & $6.6(4.2)$ & $6.6(3.7)$ \\
\hline \multirow[t]{2}{*}{ Restorative teeth } & Upper & $4.9(3.5)$ & $4.7(3.5)$ & $3.8(3.4)$ & $4.0(3.5)$ \\
\hline & Lower & $3.7(1.8)$ & $3.7(2.1)$ & $3.5(3.3)$ & $3.4(2.3)$ \\
\hline
\end{tabular}

No: The subjects answered "No" to item that the mouth becomes dry and parched. Yes: The subjects answered "Sometimes or a little" and "Yes" to item that the mouth becomes dry and parched 
表 8 Relationship between symptoms about the feeling of oral dryness and form of the denture base 義歯の形態と口腔乾燥感の自覚症状

\begin{tabular}{|c|c|c|c|}
\hline \multicolumn{4}{|l|}{ Upper jaw } \\
\hline \multirow{2}{*}{$\begin{array}{l}\text { Denture } \\
\text { base }\end{array}$} & \multirow{2}{*}{$\mathrm{N}$} & \multicolumn{2}{|c|}{ Symptom of oral dryness } \\
\hline & & No & Yes \\
\hline I & 12 & $6(50.0)$ & $6(50.0)$ \\
\hline II & 7 & $2(28.6)$ & $5(71.4)$ \\
\hline III & 42 & $21(50.0)$ & $21(50.0)$ \\
\hline \multirow[t]{2}{*}{ IV } & 39 & $23(59.0)$ & $16(41.0)$ \\
\hline & \multirow{2}{*}{\multicolumn{3}{|c|}{ Subjects $(\%)$}} \\
\hline Lower jaw & & & \\
\hline \multirow{2}{*}{$\begin{array}{l}\text { Denture } \\
\text { base }\end{array}$} & \multirow{2}{*}{$\mathrm{N}$} & \multicolumn{2}{|c|}{ Symptom of oral dryness } \\
\hline & & No & Yes \\
\hline I & 17 & $9(52.9)$ & $8(47.1)$ \\
\hline II & 6 & $5(83.3)$ & $1(16.7)$ \\
\hline III & 13 & $8(61.5)$ & $5(38.5)$ \\
\hline \multirow[t]{2}{*}{ IV } & 64 & $30(46.9)$ & $34(53.1)$ \\
\hline & \multicolumn{3}{|c|}{ Subjects $(\%)$} \\
\hline \multicolumn{4}{|c|}{ Upper and lower jaws } \\
\hline \multirow{2}{*}{$\begin{array}{l}\text { Denture } \\
\text { base }\end{array}$} & \multirow{2}{*}{$\mathrm{N}$} & \multicolumn{2}{|c|}{ Symptom of oral dryness } \\
\hline & & No & Yes \\
\hline I & 7 & $3(42.9)$ & $4(57.1)$ \\
\hline II & 23 & $12(52.2)$ & $11(47.8)$ \\
\hline III & 39 & $19(48.7)$ & $20(51.3)$ \\
\hline IV & 31 & $14(45.2)$ & $17(54.8)$ \\
\hline
\end{tabular}

表 8 に義歯の形態と口腔乾燥感の自覚症状を示す. 義歯の形態では乾燥感の自覚症状に有意差は認められ なかった。

\section{IV. 考察}

\section{1. 研究方法}

柿木ら ${ }^{31}$ は, 65 歳以上の高齢者 467 名を含む 770 名 を対象に, 平成 13 年度から科学研究費補助金長寿科 学総合研究事業「高齢者の口腔乾燥症と唾液物性に関 する研究」を行っている. 本調査のアンケート内容も これに準じた，欧米のドライマウス問診票は，口腔内 の症状に関する質問のほかに, 目や関節の症状, 日常 生活での精神的な状態についての質問事項が加えられ ている ${ }^{1)}$. 今回のアンケート調査は, 基本的な口腔乾 燥感および全身状態, 服用薬剤などに絞って行った。 アンケート調査の質問事項のなかで，20～29 歳群の 乾燥感自覚者は「口臭が気になる」を, 義歯装着者群 では「口の中がネバネバする，話しにくい」，「乾いた
食品が食べにくい」,「口で息をする」，「義歯で傷がつ きやすい」，「夜中に起きて水を飲む」などを同時に自 覚している確率が高かった。腔乾燥感に関するアン ケート調査では，これらの事項が有効であることが再 確認された。

口腔乾燥感に関与する義歯の因子としては, 義歯の 形態や材質，咬合関係，適合度などがあげられる。し かし咬合関係や適合度の簡易的な評価は難しく，今回 は義歯の形態や材質について検討を行った．義歯が装 着されていない状態を I 型, 全部床義歯を代表とする 口蓋および舌側粘膜をすべて覆う形態の義歯をIV型と して, 装着されている義歯を形態により I 〜 IV型に分 類した。 また上下顎を一口腔単位として, 義歯の組み 合わせにより 4 群に分類した。

\section{2. 口腔乾燥感について}

1）年齢による比較

Ship らは 29〜72 歳の 50 名を約 10 年間観察し, 唾 液分泌量に変化がないこと帛を，さらに 26〜90 歳の 37 名の耳下腺および顎下腺の刺激時および安静時唾 液量を 3 年間にわたり観察し, 3 年間で有意差が認め

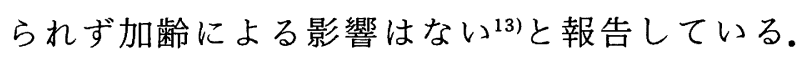
Navazesh ら ${ }^{11}$ は, 加齢により安静時唾液量は有意に 減少するが, 刺激時唾液量は有意に増加すると報告し ている. Wu ら ${ }^{122} は$, 経年的な唾液分泌の減少や唾液 に含まれる総タンパク量の減少はみられず，これらの 減少は非常に長期もしくは高齢者群の比較でみられた としている.このように加齢と唾液分泌能に関して は，見解は一致していない。

柿木ら ${ }^{3)}$ の調査 (病院入院患者や介護保険関連施設 入所者も含む) では，口腔乾燥感自覚者（「ある」 「時々・少し」を含む) は 20 ～ 29 歳 $34.8 \% ， 40 ４ 9$ 歳 $56.1 \%, 50 \sim 59$ 歳 $62.3 \%, 60 \sim 69$ 歳 $61.8 \%, 70$ 〜 79 歳 $57.8 \%, 80 \sim 89$ 歳 $55.9 \%$ であり, 65 歳以上 の高齢者における口腔乾燥感の発現頻度は軽度を含め ると $54.9 \%$ であった．本調査では，20２9 歳群，義 歯装着者群ともに, 乾燥感自覚者の出現率は柿木らの 調査よりやや低いものの, 同様の傾向にあった. 花井 ら ${ }^{16)}$ はアンケート調査の結果, 高齢群で口腔乾燥があ る人は 45 名中 20 名 $(44.4 \%)$ であり, 若年者では 30 名中 3 名 $(10.0 \%)$ であったと報告している. 本 調査を含めいずれの調査においても，若年者のほうが 
明確に乾燥感自覚者は少ない結果となっている.しか し, 柿木ら ${ }^{3)}$ の調查では 40 歳以上, 本調査において も 50 歳以上の乾燥感自覚者の発現率は加齢に伴い増 加する傾向にはなく，各年代ともほとんど変化が認め られなかった。植田ら ${ }^{17}$ は, 唾液分泌低下症 211 例の うち口腔乾燥の随伴症状がみられたのが $40 \%$ 未満で あったと報告している．若年者と中高齢者の乾燥感自 覚者発現率の相違は，唾液分泌能の差によるとも考え られるが，植田らの報告にあるようにほかの要因も考 慮に入れ検討する必要がある.

松坂ら ${ }^{18)}$ の平均年齢 $21.03 \pm 2.49$ の 203 名に対する 調査では，口腔乾燥感が「ある」ものは $15 \%$,「とき どきある」ものは $55 \%$,「ない」ものは $30 \%$ であっ た。また口腔乾燥感のあるもののほうがないものに比 べ「緊張一不安」,「疲労」,「混乱」,「抑鬱一落ち込 み」などが高く，口腔乾燥には心理的要因が多く含ま れていると示唆した. Bergdahl ら ${ }^{191}$ は口腔乾燥感が 年齢, 性別, 薬剤, ストレス, うつ状態と関連してい ると述へ，寺岡 ${ }^{20)}$ は服薬状態に加えて特性不安（不安 になりやすい性格傾向）との関連を報告している．今 回のアンケート調查は心理的要因を示す項目を含んで おらず，乾燥感自覚者の発現率にかかわる因子につい ては，さらに調査が必要と思われた。

2）他の関連因子について

口腔乾燥症は病気などの症状として発生するもの と, 治療に伴って発生してくるものとに分けられる。 病気などの症状としてはシェーグレン症候群, 糖尿 病，ストレス，口呼吸などで，治療に随伴するものは 薬の副作用, 放射線療法, 唾液腺の外科的切除などが ある。特に循環器疾患, 精神疾患, 胃潰瘍, アレル ギーなどの治療薬の副作用は影響が大きく，高齢者の 口腔乾燥の多くは薬の副作用に起因しているといわれ ている ${ }^{21)}$. Nissen ${ }^{22)}$ は，唾液腺は組織学的には若年 者と高齢者の違いが明らかであるが，臨床的には唾液 分泌量は服薬さえなりれば加齢による変化はないと結 論し，歯科的に高齢者とは唾液分泌に影響する多くの 全身疾患と薬物投与を受けている人たちであると定義 している. Ikebe ら ${ }^{23}$ は, 覚醒時に口腔乾燥感のある ものは男性, BMI が低い值，2種類以上服薬してい るものに多く, 食事中に口腔乾燥感のある人は BMI が低い值，上顎に義歯を装着しているものに多いと報 告している.
本調査では，20～29 歳群では全身状態以外のすべ ての調査項目に, 義歯装着者群でも年齢, 性別, BMI，全身状態，服薬，喫煙などのいずれにおいて も乾燥感の自覚症状に有意差は認められなかった．特 に, 口腔乾燥と密接な関連因子として挙げられる「服 薬」は, 薬剤の種類, 服薬状況ともに有意差が認めら れなかった。この主な原因は，義歯装着者群 100 名の うち投薬を受けているものは約半数で，薬剤の種類に 分けるとさらに被検者数が少なくなったことによると 思われた。

\section{3. 義歯装着者群におけるロ腔乾燥感と義歯}

義歯を装着すると唾液の分泌量が増加し, その増加 率は安静時唾液において最も大きいとされている24). 菊谷ら ${ }^{15)}$ の要介護高齢者 211 名に対する調査では, 義 歯装着者よりも義歯末使用者に口腔乾燥を示すものが 有意に多かったという.

Ikebe ら ${ }^{23)}$ は，地域在住高齢者 1,003 名（平均年齢 $66.3 \pm 4.2$ 歳）に調査を行い，覚醒時に口腔乾燥感の あるものは $37.8 \%$, 食事中に口腔乾燥感のあるもの は $9.1 \%$ と報告した。また，上顎の全部床義歯装着者 で覚醒時乾燥感のあるものは $43.8 \%$, 部分床義歯は $39.2 \%$, 固定性補綴装置を含む天然歯列は $36.7 \%$, 下顎では全部床義歯 $46.7 \%$, 部分床義歯 $36.7 \%$, 天 然歯列 $35.8 \%$ であったと報告している．また食事中 の乾燥感の自覚者は, 上顎全部床義歯装着者で $15.5 \%$, 部分床義歯 8.8\%, 天然歯列 8.4\%, 下顎で は全部床義歯 $15.4 \%$, 部分床義歯 $7.8 \%$, 天然歯列 $6.9 \%$ であった。本調査における乾燥感自覚者の発現 率は Ikebe らの結果よりやや高いものの，上下顎と もに全部床義歯装着者が部分床義歯, 義歯を装着して いない天然歯列よりもやや低い值を示し, 部分床義 歯，天然歯列はほほ同様の值を示した，また食事中の 乾燥感と関連のある項目で比較すると, 自覚症状のあ る者は,「乾いた食品が食べにくい」では上顎の全部 床義歯 $11.1 \%$, 部分床義歯 $30.0 \%$, 天然歯列 $16.7 \%$, 下顎の全部床義歯 $16.7 \%$ ，部分床義歯 $22.9 \%$ ，天然 歯列 $50.0 \%$ ，「味がおかしい」では上顎の全部床義歯 $16.7 \%$, 部分床義歯 $17.1 \%$, 天然歯列 $0.0 \%$, 下頇の 全部床義歯 $11.1 \%$, 部分床義歯 $15.7 \%$, 天然歯列 $16.7 \%$ で，それぞれ補緅装置による有意差は認めら れなかった．義歯の形態からみても，上下顎ともに被 
験者数の少なかったII型を除き，乾燥感自覚者の出現 率はほほ同様で，一口腔単位でも I IV型ともに大き な差は認められなかった. 本調査結果では, 1 本義歯 を装着している者と上下顎に全部床義歯を装着してい る者との間で, 乾燥感自覚者の出現率に差が認められ なかった。このように義歯装着者間では，義歯の種類 や形態，材料などによって乾燥感の自覚症状に差が認 められず，義歯に関する今回の調査項目では口腔乾燥 感との関連性はみられなかった。

\section{V. 結 論}

中高齢の義歯装着者と若年者の口腔乾燥感に関する 自覚症状の比較，さらに義歯装着者における義歯と口 腔乾燥との関連性を把握する目的で，アンケートおよ び口腔内や義歯に関する調査を行った。その結果, 口 腔乾燥感自覚者は義歯装着者では $48 \%$ を示し，20～29 歳群の $22 \%$ に比べて有意に高かった。義歯装着者群で は, 義歯の種類や形態, 材料などによって乾燥感の自 覚症状に差がみられなかった， 口腔乾燥感の発現に関 連する因子については今後さらに検討が必要である.

本論文の一部は第 111 回日本補経歯科学会学術大会 (2004 年 5 月 21 日, 東京）において発表した。

\section{文献}

1）齊藤一郎. ドライマウスの診断と治療. デンタルダイヤ 27：138-147, 2002.

2) Edgar WM, O'Mullane DM (河野正司監訳). Saliva and Oral Health（唾液一歯と口腔の健康 31-73, 東京： 医歯薬出版, 1997), 1996.

3）柿木保明, 岸本悦央, 森田知典ほか. 口腔乾燥症の自覚 症状と口腔乾燥度に関する調査研究. 科学研究費補助金 長寿科学総合研究事業「高齢者の口腔乾燥症と唾液物性 に関する研究」平成 14 年度報告書. 22-36, 2003.

4) Becks $\mathrm{H}$, Wainwright W. Human saliva XII, rate of flow of resting saliva of healthy individual. J Dent Res $22: 391-396,1943$.

5) Ben-Aryeh H, Miron D, Szargel R et al. Whole-saliva secretion rates in old and young healthy subjects. J Dent Res 63:1147-1148, 1984.

6) Kenneth A, Freedman KA (青木英夫, 清水 忠訳). Management of the geriatric dental patient (高齢者の 歯科治療 15-44, 東京：クインテッセンス出版, 1984), 1979.

7) Parvinen T, Larmas M. Age dependency of stimulated salivary flow rate, $\mathrm{pH}$, and lactobacillus and yeast concentrations. J Dent Res 61:1052-1055, 1982.

8) Heft HW, Baum BJ. Unstimulated and stimulated parotid salivary flow rate in individuals of different ages. J Dent Res 63 : 1182-1185, 1984.

9) Ship JA, Baum BJ. Is reduced salivary flow normal in old people? Lancet $336: 1507,1990$.

10) Baum BJ. Age related vulnerability. Otolaryngol Head Neck Surg 106:730-732, 1992.

11) Navazesh M, Mulligan RA, Kipnis V et al. Comparison of whole saliva flow rates and mucin concentrations in healthy caucasian young and aged adults. $\mathrm{J}$ Dent Res 71:1275-1278, 1992.

12) Wu AJ, Atkinson JC, Fox PC et al. Cross-sectional and longitudinal analyses of stimulated parotid salivary constituents in healthy, different-aged subjects. J Gerontol 48 : 219-224, 1993.

13) Ship JA, Nolan NE, Puckett SA. Longitudinal analyses of parotid and submandibular salivary flow rates in healthy, different-aged adults. J Gerontol 50 : 285-289, 1995.

14）米山武義, 柿木保明. 要介護高齢者における口腔乾燥に 対する訴えについて. 科学研究費補助金長寿科学総合研 究事業「高齢者の口腔乾燥症と唾液物性に関する研究」 平成 14 年度報告書. $42-47,2003$.

15）菊谷 武，金杉尚道，柿木保明．口腔乾燥が要介護高齢 者の口腔機能に与える影響について．科学研究費補助金 長寿科学総合研究事業「高齢者の口腔乾燥症と唾液物性 に関する研究」平成 14 年度報告書. 48-50, 2003 .

16）花井正歩，玉澤佳純，高藤道夫ほか。高齢者の味賞機能 に及ほす要因に関する研究. 老年歯学 19：94-103, 2004.

17）植田栄作, 木村 剛, 谷田豊宏ほか. 唾液分泌低下一そ の原因と唾液分泌低下に伴う口腔障害一。日口科誌 52:227-234, 2003.

18）松坂利之，三觜佳子，井上裕之ほか。回腔乾燥における 心理的要因に関する研究. 科学研究費補助金長寿科学総 合研究事業「高龄者の口腔乾燥症と唾液物性に関する研 究」平成 14 年度報告書. 73-80, 2003 .

19) Bergdahl M, Bergda J. Low unstimulated salivary flow and subjective oral dryness: Association with medication, anxiety, depression, and stress. J Dent Res $79: 1652-1658,2000$.

20）寺岡加代. 口腔乾燥症の診断基準ならびに関連因子に関 する研究. 科学研究費補助金長寿科学総合研究事業「高 齢者の口腔乾燥症と唾液物性に関する研究」平成 14 年 度報告書. 19-21, 2003.

21）岸本悦央. 口腔乾燥症の原因. 歯界展望 $100: 27-32$, 2002.

22） Nissen LC. 高齢者の口腔保健と唾夜分泌. 老年歯学 $18: 107-116,2003$.

23) Ikebe K, Nokubi T, Sajima H. Perception of dry mouth in a sample of community-dwelling older adults in Japan. Spec Care Dentistry $21: 52-59,2001$.

24）覚道幸男. 床義歯の生理学 317-321, 東京: 学建書院, 1986.

\footnotetext{
著者連絡先：高山 慈子

T230-8501 神奈川県横浜市鶴見区鶴見 2-1-3

TEL : 045-581-1001

FAX : 045-573-9599

E-mail : takayama-y @ tsurumi-u.ac.jp
} 


\title{
A Clinical Study on the Feeling of Oral Dryness in Denture Wearers
}

\author{
Part 1. Results of a Questionnaire Survey
}

\author{
Takayama Yasuko, Nishimura Katsuhiko, Tojo Toshiaki and Hosoi Toshio
}

The First Department of Prosthetic Dentistry, Tsurumi University School of Dental Medicine (Chief : Prof. Hosoi Toshio)

J Jpn Prosthodont Soc $49: 263-272,2005$

\section{ABSTRACT}

Purpose : We surveyed youths and denture wearers to evaluate the feeling of oral dryness. In the denture wearers group, we evaluated the association between dentures and feeling of oral dryness.

Materials and Methods : The survey was performed in 100 denture wearers (mean age, 66.2 \pm 8.6 years) who visited our department from June to October 2003. A similar survey was performed in 50 youths (mean age, 25.6 \pm 2.4 years, 20-29 year-old group). The survey consisted of a questionnaire and oral and denture examination. The questionnaire asked about oral dryness symptoms, general condition and current medications. The oral and denture examination examined the condition of the remaining teeth, the kinds of prosthesis, materials of dentures and form of the denture base.

Results : A feeling of oral dryness was observed in 11 of the 20-29 year-old group (22\%) and 48 denture wearers $(48 \%)$, hence the incidence was significantly higher in the denture wearers group $(\mathrm{p}<0.01)$. No association was observed between the oral dryness symptoms and age, sex, general condition, current medications, or number of residual teeth. The kinds of prosthesis (no denture, partial denture, complete denture) and form of the denture base have no relationship with the feeling of oral dryness.

Conclusions : $48 \%$ of the denture wearers had the feeling of oral dryness, and the incidence was higher than in the 20-29 year-old group. However, no association was observed between the oral dryness symptoms and dentures. Further studies are necessary to evaluate factors associated with the development of the feeling of oral dryness.

\section{Key words}

the feeling of oral dryness, questionnaire, denture wearers, denture base, current medications 